\section{DOPASTIN, AN INHIBITOR OF DOPAMINE $\beta$-HYDROXYLASE}

Sir :

An active inhibitor of dopamine $\beta$-hydroxylase was obtained from a cultured mushroom, but was produced by a bacterium growing with the mushroom. This organism was isolated on glucose nutrient agar on which it grew moderately. On nutrient agar without glucose it grew poorly. In this paper, we report isolation, structure and activity of dopastin.

The dopastin-producing strain (No. BAC125 of the Institute of Microbial Chemistry) is a Gram-negative oval rod with polar flagella (monotrichous) which could be shown by electronmicroscopy. Soluble pigment was not produced. It grew at $25^{\circ} \mathrm{C}$, but not or poorly at $37^{\circ} \mathrm{C}$. The optimum temperature for growth was $25 \sim 30^{\circ} \mathrm{C}$. It oxidized glucose and produced acids. After the growth, litmus milk turned very slightly alkaline and did not give an odor. Gelatin was not liquefied. Nitrate was reduced to nitrite. Thus, this organism was classified as a member of Pseudomonas. The optimum $\mathrm{pH}$ for the growth was $6.0 \sim 7.0$.

The dopastin-producing strain was shakecultured in a medium containing $2.0 \%$ glucose, $0.5 \%$ peptone, $0.3 \%$ yeast extract, $0.3 \% \mathrm{~K}_{2} \mathrm{HPO}_{4}$ and $0.1 \% \mathrm{MgSO}_{4} \cdot 7 \mathrm{H}_{2} \mathrm{O}, \mathrm{pH}$ 6.0 , for 24 hours at $30^{\circ} \mathrm{C}$, and $500 \mathrm{ml}$ of the cultured broth thus obtained was inoculated into 16 liters of the same medium placed in a jar fermentor of 30-liter volume. Silicon antifoaming agent $(10 \mathrm{ml})$ was added. The fermentation was carried out at $30^{\circ} \mathrm{C}$ for 64 hours under aeration of 16 liters/minute and stirring at $250 \mathrm{rpm}$. The activity to inhibit dopamine $\beta$-hydroxylase of culture filtrates at various fermentation times was tested by a method described in a previous paper ${ }^{1}$. Then, when $0.02 \mathrm{ml}$ of the filtrate was added to the reaction mixture of dopamine $\beta$ hydroxylase reaction, the following percent inhibition and the $\mathrm{pH}$ were observed at the following fermentation hours: $5.2 \%$ at 16 hours ( $\mathrm{pH} 5.4), 8.3 \%$ at 24 hours ( $\mathrm{pH} 5.5$ ), $50.9 \%$ at 40 hours ( $\mathrm{pH} 4.6), 69.0 \%$ at 48 hours ( $\mathrm{pH} 3.4), 72.6 \%$ at 64 hours ( $\mathrm{pH} \mathrm{5.4).}$
The culture filtrate at 64 hours was roughly estimated to contain $150 \mathrm{mg}$ of dopastin per liter.

The cultured broth obtained by the jar fermentation at 64 hours was filtered, and to the filtrate (16 liters) active carbon (160 g) was added. After 30 minutes it was. filtered. The carbon cake was washed with 10 liters of water and adsorbed dopastin was: eluted three times with $50 \%$ methanol in $0.2 \mathrm{~N}$ $\mathrm{NH}_{4} \mathrm{OH}$ (4.0 liters). The eluate (11.5 liters), was evaporated, and made $\mathrm{pH} 2.0$ and was extracted twice with butyl acetate ( 5.0 liters). Dopastin in the butyl acetate was transferred into water (3.0 liters) at $\mathrm{pH}$ 8.0. Dopastin was again transferred into butyl acetate $(2.0$ liters) at $\mathrm{pH} 2.0$ and the butyl acetate extract was concentrated to a brown residue $(4.8 \mathrm{~g})$. It was dissolved in benzene and subjected to silica gel $(300 \mathrm{ml})$ column chromatography. The column was washed with benzene $(800$ $\mathrm{ml}$ ), and dopastin was eluted with benzenemethanol ( $100: 15$ in volume). Then, dopastin appeared in the fraction between 2.0 liters. and 2.3 liters. After concentration of the active eluate under reduced pressure, a brown powder $(2.4 \mathrm{~g})$ was obtained. It was purified by silica gel $(100 \mathrm{ml})$ column chromatography using chloroform. Dopastin appeared in the fraction between $400 \mathrm{ml}$ to $500 \mathrm{ml}$, and concentration gave an active powder $(1.1 \mathrm{~g})$ which gave dopastin crystals ( $485 \mathrm{mg}$ ) by crystallization from $n$-hexane-acetone. Partition coefficients of dopastin were as follows: butanol/water 27 at $\mathrm{pH} 2.0,0.15$ at $\mathrm{pH} 8.0$; ethyl acetate/water $>10$ at $\mathrm{pH}$ $2.0,<0.1$ at $\mathrm{pH} 8.0$; butyl acetate/water 9.4 at $\mathrm{pH} 2.0,<1.0$ at $\mathrm{pH} 8.0$; chloroform water $>10$ at $\mathrm{pH} 2.0,<0.1$ at $\mathrm{pH}$ 8.0. Repetition of extraction with an organic solvent at acid and extraction with water at alkaline gave easily purified dopastin.

Dopastin, colorless needle crystals, meited at $116 \sim 119^{\circ} \mathrm{C}$. It was soluble in methanol, butanol, acetone, chloroform and alkaline water, less soluble in water, ethyl acetate, butyl acetate and benzene, and insoluble in petroleum ether and hexane. It showed strong levorotation: $[\alpha]_{\mathrm{D}}^{22}-250^{\circ}$ (c 0.5 , ethanol). The ultraviolet spectrum is shown in Fig. $1\left(\lambda_{\max } 213 \mathrm{~m} \mu\left(\mathrm{E}_{\mathrm{lcm}}^{\mathrm{1 \%}} 840\right)\right.$ and $245 \mathrm{~m} \mu$ $\left(\mathrm{E}_{\mathrm{lem}}^{1 \%} 490\right)$ in phosphate buffer of $\mathrm{pH} 7.0$ ), 
$215 \mathrm{~m} \mu\left(\mathrm{E}_{1 \mathrm{~m}}^{1 \%} 970\right)$ in $0.01 \mathrm{~N} \mathrm{HCl} ; 213 \mathrm{~m} \mu\left(\mathrm{E}_{1 \mathrm{~cm}}^{1 \%}\right.$ $830)$ and $246 \mathrm{~m} \mu\left(E_{1 \mathrm{~m}}^{1 \%} 500\right)$ in $0.01 \mathrm{~N} \mathrm{NaOH}$. It gave positive RYDON-SMITH and negative ferric chloride, Ehrlich, Tollens and ninhydrin reactions. $\mathrm{Rf}$ on thin-layer chromatography using silica gel $\mathrm{G}$ and chloroformmethanol (5:1 in volume) was 0.40 0.45.

The formula, $\mathrm{C}_{9} \mathrm{H}_{17} \mathrm{~N}_{3} \mathrm{O}_{3}$ was calculated from the analytical data, calcd.: C $50.22, \mathrm{H}$ 7.96, N 19.52, O 22.30; found: C 49.96, H $8.13, \mathrm{~N} 19.33$, O 22.67, and this formula was supported by nmr (deuterobenzene) in which all 17 protons were identified as shown in Fig. 2. Application of double resonance technique indicated the presence of crotonyl moiety including the trans configuration and 2-substituted isopentylamino moiety. Crotonic acid was obtained by hydrolysis in $1 \mathrm{~N} \mathrm{HCl}$ at $105^{\circ} \mathrm{C}$ for 3 hours, and identified by gas chromatography of its methyl ester. The amide bond was shown by positive RYDon-SMith reaction and the infrared spectrum $\left(1635,1535 \mathrm{~cm}^{-1}\right)$. The presence of nitroso group was suggested by positive Liebermann reaction. The nitrosohydroxylamino group and its location were shown by high resolution mass spectroscopy, as shown in Fig. 2. Thus, the structure in Fig. 2 was suggested and was finally proved by the degradation results.

Mild degradation in $0.1 \mathrm{~N} \mathrm{HCl}$ at $80^{\circ} \mathrm{C}$ for 24 hours gave compound A (Fig. 2). The molecular formula, $\mathrm{C}_{9} \mathrm{H}_{15} \mathrm{NO}_{2}$, was shown by mass spectroscopy. Crotonyl and isopropyl moieties were shown by $\mathrm{nmr}$ in deuterobezene. The ketone group was shown by the band at $1720 \mathrm{~cm}^{-1}$ which was absent in dopastin and by a positive 2,4-dinitrophenylhydrazine reaction which was negative in dopastin. The location of the ketone group was shown by mass spectroscopy (Fig. 2). The multiplet signal ( $e$ and $e^{\prime}$ in. Fig. 2) of two protons adjacent to imino group in dopastin collapsed to a doublet $(\delta=4.02)$ in the compound A. Thus, the structures of A is $N$-(2-oxopentyl) crotonamide.

The treatment of dopastin in $50 \%$ acetic acid at room temperature for 20 hours gave compounds $\mathrm{B}$ and $\mathrm{A}$. Compound $\mathrm{B}$ was crystallized from ethyl acetate, colorless needles, m.p. $138 \sim 139^{\circ} \mathrm{C}$. The formula $\mathrm{C}_{9} \mathrm{H}_{16} \mathrm{~N}_{2} \mathrm{O}_{2}$ was calculated from the analytical result. The nmr of the compound $B$ was similar to nmr of the compound A except

Fig. 1. Ultraviolet spectra of dopastin in neutral (phosphate buffer, pH $7.0)$, acidic $(0.01 \mathrm{~N} \mathrm{HCl})$ and alkaline solution $(0.01 \mathrm{~N} \mathrm{NaOH})$

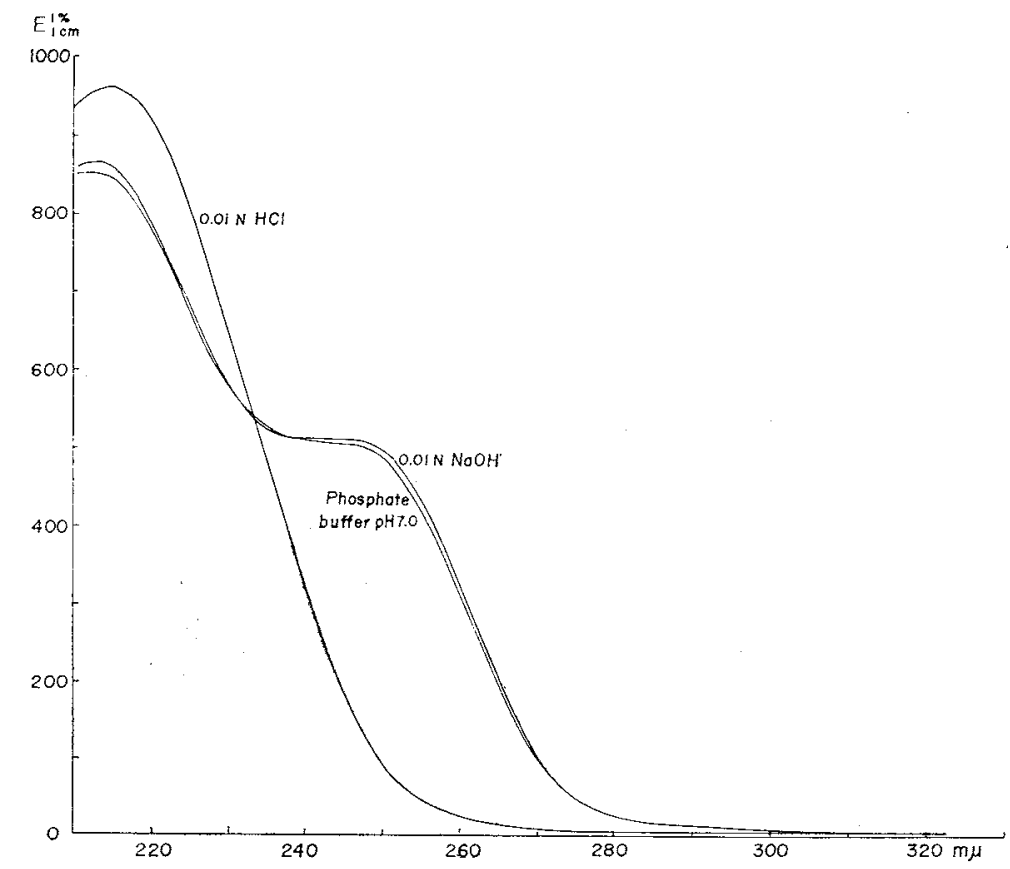


Fig. 2. The nmr spectrum of dopastin taken in deuterobenzene and degradation to compounds $\mathrm{A}$ and $\mathrm{B}$<smiles>C/C=C/C(=O)NCC(C)O</smiles>

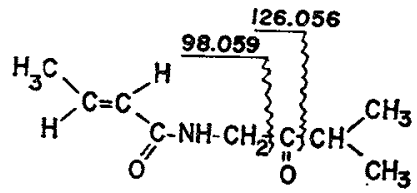

\section{Compound $B$}

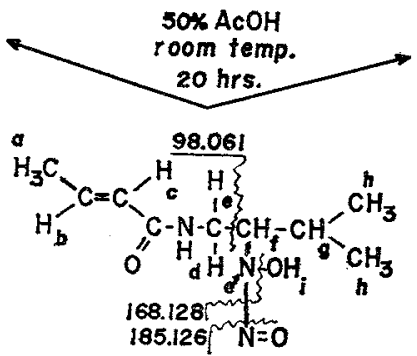

Compound A

$0.1 \times \mathrm{HCl}$

$80^{\circ} \mathrm{C}, 24 \mathrm{hrs}$.

\section{Dopastin $\left(\mathrm{C}_{9} \mathrm{H}_{17} \mathrm{~N}_{3} \mathrm{O}_{3}\right)$}

\begin{tabular}{c|c|c|c}
\hline Proton & Chemical shift $(\delta)$ & Multiplicity & Coupling constant \\
\hline $\mathrm{a}$ & 1.38 & $\mathrm{~d}, \mathrm{~d}$ & $\mathrm{Jab} 7.0$ \\
$\mathrm{~b}$ & 5.16 & $\mathrm{~m}$ & $\mathrm{Jbc} 14.8$ \\
$\mathrm{c}$ & 6.80 & $\mathrm{~m}$ & $\mathrm{Jac} 1.5$ \\
$\mathrm{~d}$ & 5.12 & $\mathrm{t}$ & $\mathrm{Jde} 6.6 \mathrm{Jde} 6.5$ \\
$\mathrm{e}$ & 3.32 & $\mathrm{~m}$ & $\mathrm{Jee}^{\prime} 14.0$ \\
$\mathrm{e}^{\prime}$ & 3.62 & $\mathrm{~m}$ & Jef 9.0 \\
$\mathrm{f}$ & 4.06 & $\mathrm{~m}$ & $\mathrm{Je}$ \\
$\mathrm{g}$ & 1.93 & $\mathrm{~m}$ & $\mathrm{Jfg} 9.0$ \\
$\mathrm{~h}$ & $0.61,0.67$ & $\mathrm{~d}$ & $\mathrm{Jgh} 7.0$ \\
$\mathrm{i}$ & 12.02 & $\mathrm{~s}$ & - \\
\hline
\end{tabular}

Fig. 3. Lineweaver-Burk plots of ascorbic acid concentration against rate of hydroxylation with and without dopastin

Incubation was for 30 minutes. The velocities are expressed as $\mu$ moles of norsynephrine formed from tyramine. The substrate concentration is expressed in moles.

A: enzyme alone, B: enzyme with $2.33 \times 10^{-6} \mathrm{M}$ dopastin, C : enzyme with $4.65 \times 10^{-6} \mathrm{M}$ dopastin.

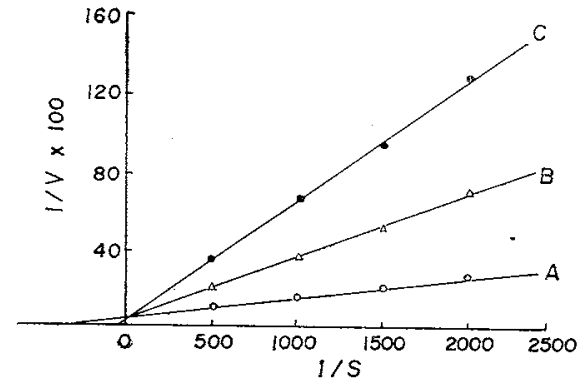

for a singlet at $\delta 9.7$ which could be assigned to an oxime proton.

When the activity to inhibit dopamine $\beta$ hydroxylase was determined by the method described in a previous paper ${ }^{1)}, 4.7 \times 10^{-6} \mathrm{M}$
Fig. 4. Lineweaver-Burk plots of tyramine concentration against rate of hydroxylation with and without dopastin

Incubation was for 30 minutes. The velocities are expressed as $\mu$ moles of norsynephrine formed from tyramine. The substrate concentration is expressed in moles.

A: enzyme alone, B: enzyme with $2.33 \times 10^{-6} \mathrm{M}$ dopastin, $\mathrm{C}$ : enzyme with $4.65 \times 10^{-6} \mathrm{M}$ dopastin, D: enzyme with $9.30 \times 10^{-6} \mathrm{M}$ copastin.

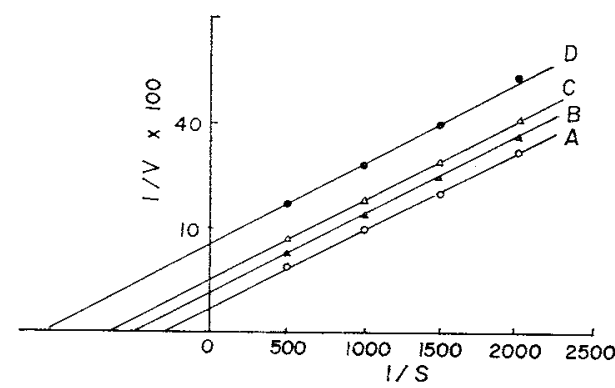

$(1.0 \mu \mathrm{g} / \mathrm{ml})$ showed $50 \%$ inhibition. In the kinetic studies, as shown in Figs. 3 and 4, dopastin was competitive with the cofactor (ascorbic acid) and uncompetitive with the substrate (tyramine). These modes of inhibi- 
Fig. 5. Mean systolic pressures in SH-rats at various weeks of age and depressor responses to dopastin

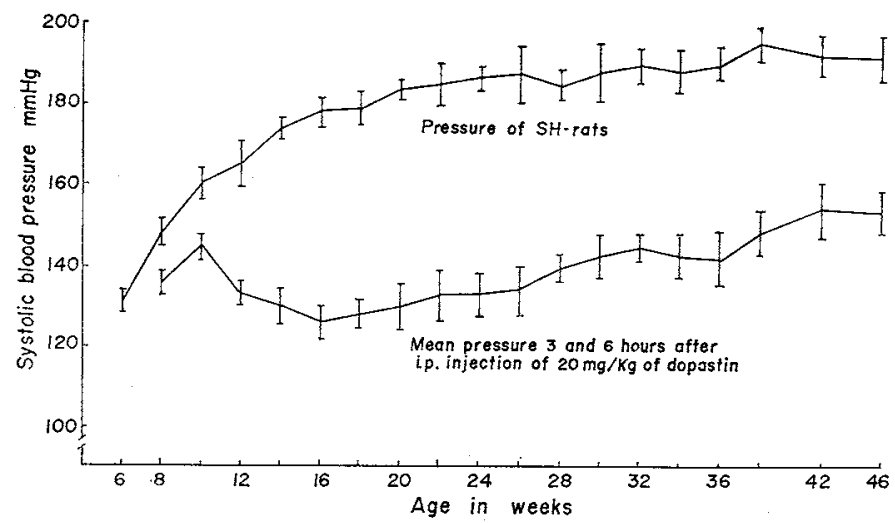

tion were same as those observed in 5pentylpicolinic acid ${ }^{1)}$. Dopastin showed a hypotensive effect in spontaneously hypertensive rats, as shown in Fig. 5. Dopastin has low toxicity (oral $\mathrm{LD}_{50} 750 \mathrm{mg} / \mathrm{kg}$, i.p. $\mathrm{LD}_{50}$ $460 \mathrm{mg} / \mathrm{kg}$ in mice), and the intravenous injection of $250 \mathrm{mg} / \mathrm{kg}$ killed no mice. A subacute toxicity test in rats showed no toxic reaction except decrease of the blood pressure.

Dihydrodopastin which was obtained by hydrogenation of dopastin with platinum oxide showed the same activity to inhibit dopamine $\beta$-hydroxylase and to reduce the blood pressure as dopastin. Among known products, fragin reported by TAmura et al..$^{2)}$ is structurally related to dihydrodopastin and might have similar activity. Fragin is phytotoxic. Dopastin at $10 \mu \mathrm{g} / \mathrm{ml}$ showed $50 \%$ inhibition of germination of barley seed.

Nitrosohydroxylamino group in dopastin is thought to be the active group, because the compounds $\mathrm{A}$ and $\mathrm{B}$ showed no biological activity. However, the activity is influenced by neighboring groups. Alanosine ${ }^{3)}, \mathrm{L}_{-}-2$ amino-3-nitrosohydroxylaminopropionic acid, showed 50 times less activity in inhibiting dopamine $\beta$-hydroxylase. Compared to alanosine, dopastin showed much lower cytotoxicity: only $26.5 \%$ inhibition of Yoshida rat sarcoma cells was observed in a medium containing $25 \mu \mathrm{g} / \mathrm{ml}$ of dopastin. Dopastin is an interesting compound in the relation of its structure to the activity.

Hironobu Iinuma

Tomio Takeuchi

Shinichi Kondo

Meiki Matsuzaki

Hamao Umezawa

Institute of Microbial Chemistry, Kamiosaki, Shinagawa-ku, Tokyo, Japan

$$
\text { Masaji Ohno }
$$

Basic Research Laboratories, Toray Industries, Inc., Kamakura, Japan

(Received June 6, 1972)

\section{References}

1) Suda, H.; T. Takevechi, T. Nagatsu, M. Matsuzaki, I. Matsumoto \& H. Umezawa: Inhibition of dopamine $\beta$-hydroxylase by 5-alkylpicolinic acid and their hypotensive effects. Chem. Pharm. Bull. $17: 2377 \sim 2386$, 1969

2) Murayama, A. \& S. Tamura: Über Fragin, ein neues biologisch actives Stoffwechselprodukt von Pseudomonas fragi. Agr. Biol. Chem. $34: 122 \sim 129,1970$

3) Lanoini, G. C.; A. Diena \& E. Lazzari : The synthesis of alanosine. Tetrahedron Letters $1966: 1769 \sim 1772,1966$ 